\title{
Diversity of planktonic fish larvae along a latitudinal gradient in the Eastern Atlantic Ocean estimated through DNA barcodes
}

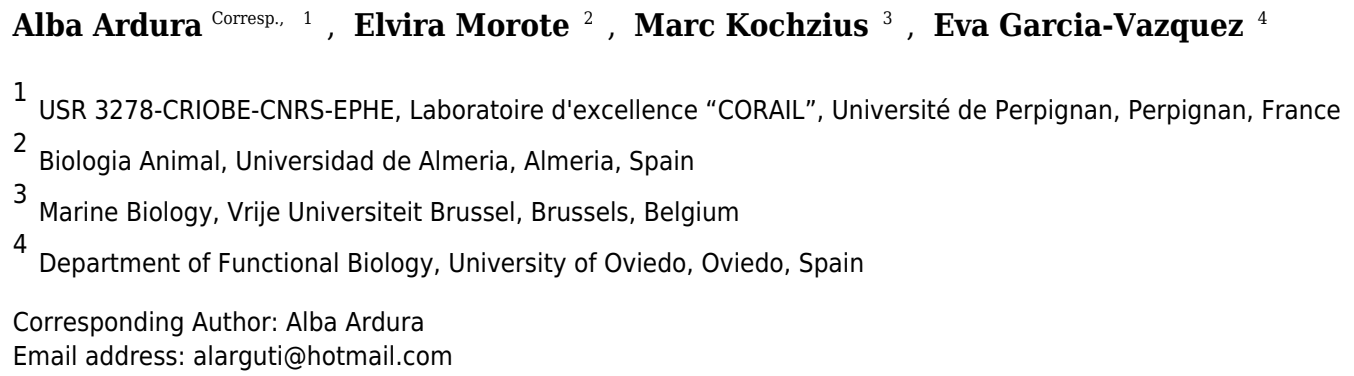

Mid-trophic pelagic fish are essential components of marine ecosystems, because they represent the link between plankton and higher predators. Moreover they are the basis of the most important fisheries resources, for example in African waters. In this study we have sampled pelagic fish larvae in the Eastern Atlantic Ocean along a latitudinal gradient between $37^{\circ} \mathrm{N}$ and $2^{\circ} \mathrm{S}$. We have employed Bongo nets for plankton sampling and sorted visually fish and fish larvae. Using the cytochrome oxidase I gene (COI) as a DNA barcode we have identified 44 OTUs down to species level that correspond to 14 families, Myctophidae being the most abundant. A few species were cosmopolitan and others latitude-specific, as expected. The latitudinal pattern of diversity did not exhibit a temperate-tropical cline; instead it was likely correlated with environmental conditions with a decline in low-oxygen zones. Importantly, gaps and inconsistencies in reference DNA databases impeded accurate identification to the species level of $49 \%$ of the individuals. Fish sampled from tropical latitudes and some orders, such as Perciformes, Myctophiformes and Stomiiformes, were largely unidentified due to incomplete references. Some larvae were identified based on morphology and COI analysis for comparing time and costs employed from each methodology. These results suggest the need of reinforcing DNA barcoding reference datasets of Atlantic bathypelagic tropical fish that, as main prey of top predators, are crucial for ecosystem-based management of fisheries resources. 
1 Diversity of planktonic fish larvae along a latitudinal gradient in the Eastern Atlantic

2 Ocean estimated through DNA barcodes

3

4 Alba Ardura ${ }^{*}$, Elvira Morote ${ }^{2}$, Marc Kochzius $^{3}$, Eva Garcia-Vazquez ${ }^{4}$

5 1: USR 3278-CRIOBE-CNRS-EPHE, Laboratoire d'excellence "CORAIL", Universite de 6 Perpignan-CBETM, 58 Rue Paul Alduy, 66860 Perpignan CEDEX, France

7 2: Universidad de Almeria, Carretera de Sacramento s/n. 04120, Almeria

8 3: Marine Biology, Vrije Universiteit Brussel, Pleinlaan 2, 1050 Brussels, Belgium

9 4: Department of Functional Biology, University of Oviedo. C/ Julian Claveria s/n 3300610 Oviedo, Spain

$11{ }^{*}$ Corresponding author:

12 Alba Ardura, alarguti@hotmail.com

13 


\section{Abstract}

Mid-trophic pelagic fish are essential components of marine ecosystems, because they represent the link between plankton and higher predators. Moreover they are the basis of the most important fisheries resources, for example in African waters. In this study we have sampled pelagic fish larvae in the Eastern Atlantic Ocean along a latitudinal gradient between $37^{\circ} \mathrm{N}$ and $2^{\circ} \mathrm{S}$. We have employed Bongo nets for plankton sampling and sorted visually fish and fish larvae. Using the cytochrome oxidase I gene (COI) as a DNA barcode we have identified 44 OTUs down to species level that correspond to 14 families, Myctophidae being the most abundant. A few species were cosmopolitan and others latitude-specific, as expected. Importantly, gaps and inconsistencies in reference DNA databases impeded accurate identification to the species level of $49 \%$ of the individuals. Fish sampled from tropical latitudes and some orders, such as Perciformes, Myctophiformes and Stomiiformes, were largely unidentified due to incomplete references. Some larvae were identified based on morphology and $\mathrm{COI}$ analysis for comparing time and costs employed from each methodology. These results suggest the need of reinforcing DNA barcoding reference datasets of Atlantic bathypelagic tropical fish that, as main prey of top predators, are crucial for ecosystem-based management of fisheries resources.

\section{Introduction}

Bathypelagic and mesopelagic fish are important components of plankton, so largely unknown that they have been even called the missing biomass (e.g. Johnson et al., 2011). They represent an important part of lower levels in the trophic chain that ends in cetaceans as well as other top predators (e.g. Bulman, He \& Koslow, 2002; Walker, Mead \& Brownell, 2002), and are especially sensitive to climate change and other environmental alterations (e.g. Boeing \& DuffyAnderson 2008, ).

An inventory of the ichthyoplankton community is therefore essential for understanding how the trophic chain and by extension the whole ecosystem function, as well as for timely prediction of changes due to ichthyoplankton alterations. Indeed, such inventory requires accurate species identification of all fish, fish larvae and eggs present in plankton samples. In some regions DNA is employed for species identification of fish eggs and larvae, and there are species-specific markers useful for this purpose in several fish groups of interest such as megrims and hakes (Perez et al., 2005; Von der Heyden et al., 2007), cod (Fox et al., 2005), horse-mackerel (Karaiskou et al., 2007) and others. Other ichthyoplankton communities however are lesser known.

DNA barcoding is a methodology that enables accurate identification of fish species (e.g. Ward et al., 2005; Kochzius 2009; Kochzius et al., 2010; Pappalardo et al., 2015). It was employed to identify blue mackerel eggs and larvae in Australian waters (Neira \& Keane, 2008), Antarctic 
52 fish (Dettai et al., 2011; Belchier \& Lawson, 2013), coral reef ichthyoplankton (Hubert et al., 53 2015) and Amazonian fish (Ardura et al., 2010). Barcode of Life projects are considered a 54 promising tool to identify all species, given expectations of massive decrease in analysis costs 55 (Edwards et al., 2010). Today, however, DNA-based methodologies are not routinely employed 56 and the task of ichthyoplankton inventory relies on the taxonomical expertise of zoologists and

57

58 marine biologists specialized in local pelagic fauna in many regions. A problem is the absence of detailed descriptions of early stages for many species, thus identifying individuals to the species level is frequently impossible. The number of larval fish descriptions for a given region is often inversely related to faunal diversity (Fahay, 2007). Following the taxonomic sufficiency approach, Hernandez et al. (2013) suggested analyses at the genus level can be a good proxy when examining assemblage diversity.

In this study we have applied DNA barcoding for identification of fish larvae sampled from a latitudinal gradient in the Eastern Atlantic Ocean. The objective was to identify current needs for the full application of DNA barcoding to the inventory of planktonic fish in large scale surveys. We have employed the methodology proposed by the Fish barcoding of Life initiative (FISHBOL; Ward et al., 2009.

\section{Material and Methods}

\section{Sampling}

During the cruise of the RV Polarstern, fish larvae were obtained by means of oblique Bongo hauls (mesh size of $0.5 \mathrm{~mm}$ ) from a depth of $200 \mathrm{~m}$ depth to the surface. One Bongo net sample was designated to barcoding analysis while the samples from the other Bongo net were used for visual taxonomic identification. After hauling the net back on the deck the cod end of the Bongo net was poured in a bucket and the net was rinsed. To avoid damage to the fish larvae, the codend-containing larvae for visual taxonomic identification was removed before the net was washed down. The rinsed sample was kept in a separate bucket. The whole sample was examined for fish larvae.

The samples from the net allocated to visual identification were divided at random (haphazardly) in two parts. One was employed for other purposes (teaching project within the cruise EUROPA), and the other was examined under binocular microscope. Fish were identified de $v i s u$, sorted manually and stored in $96 \%$ ethanol until genetic analysis. A few individuals were taxonomically classified to the lowest taxonomic level using a stereomicroscope (Leika MS5) and identification guides (Olivar \& Fortuno 1991; Boltovskoy 1999; Richards 2005) for comparison of visual identification with DNA barcoding methodology. Insights on diagnostic morphological traits from the online database FishBase (Froese \& Pauly, 2016) were also used. 
87 Abundances for the different groups were calculated in individuals per $1000 \mathrm{~m}^{3}$. The volume of 88 water filtered by the net was estimated using a flow meter (Hydro bios) attached to one Bongo 89 net.

90 The locations and coordinates of the sampling sites are provided in Fig. 1.

91

92

\section{DNA barcoding}

Total DNA was extracted from a small piece of tissue following the standard protocol described by Estoup et al. (1996), employing Chelex ${ }^{\circledR}$ resin (Bio-Rad Laboratories). The tubes were stored at $4{ }^{\circ} \mathrm{C}$ for immediate DNA analysis, and aliquots were frozen at $-20{ }^{\circ} \mathrm{C}$ for longtime preservation.

A fragment of the COI gene was amplified by polymerase chain reaction (PCR), employing the primers described by Ward et al. (2005). The amplification reaction was performed in a total volume of $40 \mu$, with Promega (Madison, WI) buffer $1 \mathrm{X}, 2.5 \mathrm{mM} \mathrm{MgCl}, 0.25 \mathrm{mM}$ dNTPs, 20 pmol of each primer, approximately $20 \mathrm{ng}$ of template DNA and $1 \mathrm{U}$ of DNA Taq polymerase (Promega), and the following PCR conditions: initial denaturing at $95{ }^{\circ} \mathrm{C}$ for $5 \mathrm{~min}, 35$ cycles of denaturing at $95{ }^{\circ} \mathrm{C}$ for $20 \mathrm{~s}$, annealing at $57{ }^{\circ} \mathrm{C}$ for $20 \mathrm{~s}$, extension at $72{ }^{\circ} \mathrm{C}$ for $30 \mathrm{~s}$ and final extension at $72{ }^{\circ} \mathrm{C}$ for $10 \mathrm{~min}$.

Sequencing was performed with the DNA sequencing service Macrogen Europe (The Netherlands).

\section{Species identification based on DNA}

Sequences were visualized and edited with the programme BioEdit Sequence Alignment Editor (Hall, 1999) and aligned with ClustalW (Thompson et al., 1994) as implemented in BioEdit. First the sequences were checked for the possibility of being pseudogenes (Bensasson et al. 2001; Richly \& Leister 2004) using the putative translated protein as a quality filter, since pseudogenes rarely conserve the reading framework of true coding genes. The putative protein was inferred from the amplicons using MEGA 6 software (Tamura et al., 2013). For identifying the species, the sequences obtained were compared with international databases using the BOLD system (http://www.boldsystems.org/), based on the Hidden Markov Model (HMM) algorithm (Eddy, 1998) and the BLAST algorithm of GenBank (Altschul et al., 1990) (http://www.ncbi.nlm.nih.gov/). Besides, a Neighbour -Joining (NJ) tree has been built with a distance-based approach to illustrate the sequence identity based on tree topology. The phylogenetic analysis was performed using MEGA 6 (Tamura et al., 2013).

\section{Results}


125 DNA extraction and PCR amplification of the COI gene was successful in $90 \%$ of the samples. 126 The 237 sequences obtained had an average length of 630 nucleotides. Pseudogenes were 127 reasonably discarded since putative proteins obtained from translation of the amplicons were all 128 compatible with coding COI genes (Bensasson et al., 2001; Richly \& Leister, 2004). Not all of 129 them retrieved a significant match at species level from the reference databases (Table 1), with 130 the cutoffs used in this study ( $>97 \%$ identity, $>80 \%$ coverage) within the 97-97.4\% 131 commonly accepted for this gene in Barcoding projects (e.g. Meyer \& Paulay, 2005). In some 132 cases species identification was not possible, because two or more reference sequences of 133 different species in BOLD were identical, sometimes even from different families (Table 1). 134 These individuals were classified as ambiguities, because it was not possible to identify them using GenBank. In other cases there was clear discrepancy between the two databases, retrieving different species, sometimes even different genera. In cases of discrepancy the individual was assigned to the higher taxonomic level (Table 1). The sequences that were identified at species level in BOLD and/or by BLAST in (44 species) were submitted to GenBank (Table 2). The phylogenetic classification of these 44 species was checked with a Neighbour-Joining tree methodology (Figure 2). From the 237 individuals barcoded $121(51.1 \%)$ were assigned to a species, and $205(86.5 \%)$ to a genus (Table 1). All the individuals were assigned to an order and most of them to a family (96.6\%). Finally, a Neighbour-Joining (NJ) tree was built with a distance-based approach to illustrate the sequence identity based on tree topology (Fig. 2). The trees obtained from the two approaches were largely consistent.

The taxonomic resolution, obtained from the COI gene and the databases used as references, was different for the eight orders found in this study (Table 2). In other words, we found differences between groups of fish for their coverage within the databases employed as references. In the Myctophiformes $(\mathrm{n}=164)$ only $59 \%$ of the individuals were identified to a species level (Fig. $3)$. For the less abundant Stomiiformes $(n=32)$ and Perciformes $(n=21)$, only $28 \%$ and $19 \%$ could be identified to a species level, respectively. Since the orders were not equally abundant at all stations, and the specific resolution of the orders was different, as a result the taxonomic resolution was spatially different along the latitudinal gradient considered. The number and proportion of individuals identified to a species level was higher at the stations at higher latitudes and decreased towards the equator (Fig. 4).

Using five species of Myctophiformes (Table 2), the comparison between morphological and DNA-based species identification was done taking individuals at random from the list. These were Diogenichthys atlanticus (3 individuals in our sample), Hygophum hygomii (22 individuals), Lampanyctus alatus (1 individual), Lampanyctus pusillus (3 individuals) and Myctophum asperum (1 individual). Inconsistencies between visual taxonomic and barcoding identification were not found. The time required for identifying one individual by a researcher or technician will vary, depending on previous training and familiarity with the species and the accurate identification must be based on diagnostic characters (Table 3). Here, the identification time was estimated from the approximate time required by a trained technician to check the diagnostic traits indicated in Table 3 under the microscope or magnifying glass (depending on the size of the individual). Less time is needed if the species has a distinctive morphology within the order (big or small eyes, atypical shape, unusual characters). The main point here is that the individuals need to be examined one by one for visual classification. For DNA barcoding the time dedicated to each individual is shorter: just cutting a piece of tissue and storing it in ethanol. 
171 The process of labeling vials with adequate codes for traceability between the tissue sample and the voucher specimen can be very fast with pre-prepared labels. An experienced technician can complete DNA extraction and preparation of PCR quite rapidly (Table 4). These processes can be robotized, thus a large number of samples can be analyzed in relatively short time. In the present case, samples of $\mathrm{N}=30$ from three species were loaded simultaneously in a thermocycler of 96 wells. Briefly, more labor hours and cheaper analytical materials are required for visual analysis than for DNA barcoding. We have estimated time costs per hour using the average salary per working hour of a Spanish laboratory technician in 2015, because the laboratory analysis was done in Spain. The final cost of analyzing the 30 individuals of those five species found in our sampling was $169 €$ and $90.5 €$ for DNA barcoding and visual identification, respectively.

Most of the species were only collected at one station and only three myctophid species were found at more than two stations: Bolinichthys indicus, Hygophum hygomii and H. macrochir (Table 2).

\section{Discussion}

The main shortcoming of DNA barcoding in our study was the lack of a solid, large and robust database with reliable reference sequences. The same problem was found by Leis (2015) for Indo-Pacific fish larvae. DNA helps to establish identities of larvae when there are reference barcodes with accompanying voucher specimen taxonomically ascertained in the databases. This is not the case of a large proportion of the larvae found in plankton surveys. Therefore the enormous potential for DNA to advance larvae identification has not been properly exploited yet. An integrative approach combining genetics and diagnostic morphological traits for species identification would be strongly recommended (Leis, 2015). From our results, Atlantic pelagic fish identification through sequence similarity seems to be hampered by the incompleteness of the taxonomic coverage, as it was also found for Antarctic bony fish (Dettai et al., 2011). In addition to database incompleteness, we have found some inconsistencies in BOLD due to identical sequences assigned to different species. In this sense, generating a critical mass of BARCODE compliant specimen records and developing an error-free searchable database have been identified as critically important issues for FISH-BOL to tackle (Ward, Hanner \& Hebert, 2009). For large scale surveys of planktonic fish those inconsistencies should be solved if barcoding is to be applied. Recommendations could be, for example, curating the databases against voucher specimens and improving reference collections agreed among experts from different countries and disciplines.

In our study, a clear economic advantage has been found for visual methodology using a short subset of samples (Table 4). However, if we apply these estimates to a larger dataset the difference between methods will decrease, or turn to be advantageous for DNA-based methodologies because they can be robotized and time saved. However, equipment is objectively more expensive for DNA analysis than for visual methodology today. Cost per individual decreases are predicted for genomic methods, thus DNA barcoding-based approach is likely to become cost-effective in the near future (Edwards et al., 2010). 
216 Finally, Myctophiformes (lanternfish) and Stomiiformes (dragonfish), the most abundant taxa 217 and lacking accurate references for being identified to the species level (Fig. 3), are the critical 218 trophic link between primary producers and higher trophic levels including important fishing

219

220

221

222

223

224

225

226

227

228

229

230

231

232

233

234

235

236

237

238

239

240

241

242

243

244

245

246

247

248

249

250

251

252

253

254

255

256

257

258

259 resources such as tuna (e.g. Choy et al., 2012 and references therein). Ecosystem-based management of fishing resources (e.g. Hall \& Mainprize, 2004) would be greatly improved if diversity estimates of these important plankton components are accurate, and enhancing barcoding databases could contribute efficiently to this.

\section{Conclusions}

A lack of accurate unambiguous DNA sequence references was found for Atlantic bathypelagic fish, especially in tropical latitudes. These results emphasize the need of obtaining more genetic Barcodes for bathypelagic fish species to increase the potential utility of barcoding for diversity estimates in ecosystem-based management of fishing resources.

\section{Acknowledgments}

We would like to thank the institutions and persons that made our work possible: Alfred Wegener Institute for Polar and Marine Research (Bremerhaven, Germany); crew of RV Polarstern (ANT-XXIX/1); Holger Auel (University of Bremen, Germany), for coordinating the expedition.

\section{References}

Altschul SF, Gish W, Miller W, Myers EW, Lipman DJ. 1990. Basic local alignment search tool. Journal of Molecular Biology 215(3):403-410.

Angel MV. 1993. Biodiversity of the Pelagic Ocean. Conservation Biology 7: 760-772.

Ardura A, Line AR, Moreira J, Garcia-Vazquez E. 2010. DNA barcoding for conservation and management of Amazonian commercial fish. Biological Conservation 143:1434-1443.

Belchier M, Lawson J. 2013. An analysis of temporal variability in abundance, diversity and growth rates within the coastal ichthyoplankton assemblage of South Georgia (sub-Antarctic). Polar Biology 36:969-983.

Bensasson D, Zhang DX, Hartl DL, Hewitt GM. 2001. Mitochondrial pseudogenes: evolution's misplaced witnesses. Trends in Ecology \& Evolution 16(6): 314-321.

Boeing WJ , Duffy-Anderson JT. 2008. Ichthyoplankton dynamics and biodiversity in the Gulf of Alaska: Responses to environmental change. Ecological Indicators 8:292-302.

Boltovskoy D. 1999. South Atlantic Zooplankton C/592:S6. 
292

293

294

295

296

297

298

299

300

301

302

303

304

305

Bulman CM, He X, Koslow JA. 2002. Trophic ecology of the mid-slope demersal fish community off southern Tasmania, Australia. Marine and Freshwater Research 53(1): 59 - 72 .

Choy CA, Davison PC, Drazen JC, Flynn A, Gier EJ, Hoffman JC, McClain-Counts JP, Miller TW, Popp BN, Ross SW, Sutton TT. 2012. Global trophic position comparison of two dominant mesopelagic fish families (Myctophidae, Stomiidae) using amino acid nitrogen isotopic analyses. PLoS ONE 7(11): e50133.

Dettai A, Lautredou A-C, Bonillo C, Goimbault E, Busson F, Causse R, Couloux A, Cruaud C, Duhamel G, Denys G, Hautecoeur M, Iglesias S, Koubbi P, Lecointre G, Moteki M, Pruvost P, Tercerie S, Ozouf C. 2011. The actinopterygian diversity of the CEAMARC cruises: Barcoding and molecular taxonomy as a multi-level tool for new finding. Deep Sea Research Part II: Topical Studies in Oceanography 58:250-263.

Edwards M, Beaugrand G, Hays GC, Koslow JA, Richardson AJ. 2010. Multi-decadal oceanic ecological datasets and their application in marine policy and management. Trends in Ecology and Evolution 25:602-610.

Eddy SR. 1998. Profile hidden Markov models. Bioinformatics, 14(9):755-763.

Estoup A, Largiader CR, Perrot E, Chourrout D. 1996. Rapid one-tube DNA extraction for reliable PCR detection of fish polymorphic markers and transgenes. Molecular Marine Biology and Biotechnology 5:295-298.

Fahay MP. 2007. Early stages of fishes in the western North Atlantic Ocean, Vol I. Dartmouth, NS: Northwest Atlantic Fisheries Organization.

Fox CJ, Taylor MI, Pereyra R, Vilasana MI, Rico C. 2005. TaqMan DNA technology confirms likely overestimation of cod (Gadus morhua L.) egg abundance in the Irish Sea: implications for the assessment of the cod stock and mapping of spawning areas using egg-based methods. Molecular Ecology 14:879-884.

Froese, R. and D. Pauly. Editors. 2016. FishBase. World Wide Web electronic publication. www.fishbase.org, version (01/2016).

Hall SJ, Mainprize B. 2004. Towards ecosystem-based fisheries management. Fish and Fisheries $5: 1-20$.

Hernandez FJ Jr, Carassou L, Graham WM, Powers SP. 2013. Evaluation of the taxonomic sufficiency approach for ichthyoplankton community analysis. Marine Ecology Progress Series 491:77-90.

Hall TA, 1999. BioEdit: a user-friendly biological sequence alignment editor and analysis program for Windows 95/98/NT. Nucleic Acids Symposium Series 41:95-98. 
306

Hubert N, Espiau B, Meyer C, Planes S. 2015. Identifying the ichthyoplankton of a coral reef using DNA barcodes. Molecular Ecology Resources 15: 57-67.

Johnson CL, Runge JA, Curtis KA, Durbin EG, Hare JA, Incze LS, Link JS, Melvin GD, O'Brien TD, Van Guelpen L.. 2011. Biodiversity and Ecosystem Function in the Gulf of Maine: Pattern and Role of Zooplankton and Pelagic Nekton. PLoS ONE 6(1): e16491.

Karaiskou N, Triantafyllidis A, Alvarez P, Lopes P, Garcia-Vazquez E, Triantaphyllidis C. 2007. Horse mackerel egg identification using DNA methodology. Marine Ecology 28:429-434.

Kochzius M. 2009. Trends in fishery genetics. In: Beamish R, Rothschild B (eds) The Future of Fishery Science in North America. Fish \& Fisheries Series, Springer Science + Business Media B.V., pp 453-493.

Kochzius M, Seidel C, Antoniou A, Botla SK, Campo D, Cariani A, Garcia-Vazquez E, Hauschild J, Hervet C, Hjörleifsdottir S, Hreggvidsson G, Kappel K, Landi M, Magoulas A, Marteinsson V, Nölte M, Planes S, Tinti F, Turan C, Venugopal MN, Weber H, Blohm D. 2010. Identifying fishes through DNA barcodes and microarrays. PLoS One 5(9): e12620.

Leis JM. 2015. Taxonomy and systematics of larval Indo-Pacific fishes: a review of progress since 1981. Ichthyological Research 62:9-28.

Meyer C, Paulay, G. 2005. DNA barcoding: error rates based on comprehensive sampling. PLoS Biol 3(12):e422.

Neira FJ, Keane JP. 2008. Ichthyoplankton-based spawning dynamics of blue mackerel (Scomber australasicus) in south-eastern Australia: links to the East Australian Current. Fisheries Oceanography 17:281-298.

Olivar MP, Fortuno JM. 1991. Guide to Ichthyoplankton of the Southeast Atlantic (Benguela Current Region). Scientia Marina 55(1):1-383.

Pappalardo AM, Cuttitta A, Sardella A, Musco M, Maggio T, Patti, B, Mazzola S, Ferrito, V. 2015. DNA barcoding and COI sequence variation in Mediterranean lanternfishes larvae. Hydrobiologia 749(1):155-167.

Perez J, Alvarez P, Martinez JL, Garcia-Vazquez E. 2005. Genetic identification of hake and megrim eggs in formaldehyde-fixed plankton samples. ICES Journal of Marine Science 62:908914.

Richards WJ. 2005. Early Stages of Atlantic Fishes: An Identification Guide for the Western Central North Atlantic, Volume 1 \& 2. Boca Raton: CRC Press, Taylor \& Francis Group.

Richly E, Leister D. 2004. NUMTs in sequenced eukaryotic genomes. Molecular Biology and Evolution 21(6):1081-1084. 
352 Tamura K, Stecher G, Peterson D, Filipski A, Kumar S. 2013. MEGA6: molecular evolutionary 353 genetics analysis Version 6.0. Molecular Biology and Evolution 30:2725e2729.

354

355

356

357

358

359

360

361

362

363

364

365

366

367

368

369

370

371

372

373

374
Thompson JD, Higgins DG, Gibson TJ. 1994. Clustal-W Improving the sensitivity of progressive multiple sequence alignment through sequence weighting, position-specific gap penalties and weight matrix choice. Nucleic Acids Research Series 22(22):4673-4680.

Von der Heyden S, Lipinski MR, Matthee CA. 2007. Species specific genetic markers for identification of early life history stages of Cape hakes, Merluccius capensis and $M$. paradoxus in the southern Benguela Current. Journal of Fish Biology 70:262-268.

Ward RD, Hanner R, Hebert PDN. 2009. The campaign to DNA barcode all fishes, FISH-BOL. Journal of Fish Biology 74:329-356.

Walker WA, Mead JG, Brownell RL. 2002. Diets of Baird's beaked whales, Berardius bairdii, in the southern Sea of Okhotsk and off the Pacific coast of Honshu, Japan. Marine Mammal Science 18:902-919.

Ward RD, Zemlak TS, Innes BH, Last PR, Hebert PDN. 2005. DNA Barcoding Australia's fish species. Philosophic Transactions of the Royal Society B 360:1847-1857.

Worm B, Sandow M, Oschlies A, Lotze HK, Myers RA. 2005. Global Patterns of Predator Diversity in the Open Oceans. Science 309:1365-1369. 
376 Table 1. Assignment of COI gene sequences of fish larvae collected along a latitudinal gradient in the 377 Eastern Atlantic Ocean to taxonomic groups in the databases GenBank and BOLD. Number of sequences 378 assigned to only one of the databases, to the two of them (concordance), discrepancy between the two 379 databases (discrepancy), and ambiguous assignment due to identical match in BOLD (ambiguity), and 380 number of sequences assigned to each taxonomic level (final assignment). The sequences finally assigned 381 to a level include the concordant cases in such level plus the discrepant/ambiguous cases of the lower 382 level.

383

$\begin{array}{lllllll} & \text { GenBank } & \text { BOLD } & \text { Concordance } & \text { Discrepancy } & \text { Ambiguity } & \text { Assignal } \\ \text { Order } & 8 & 0 & 0 & 0 & 0 & 10 \\ \text { Family } & 0 & 0 & 0 & 0 & 2 & 22 \\ \text { Genus } & 0 & 5 & 11 & 4 & 18 & 84 \\ \text { Species } & 0 & 58 & 63 & 2 & 66 & 121 \\ \text { n } & 8 & 63 & 74 & 6 & 86 & 237\end{array}$


388 Table 2. Identified fish larvae along a latitudinal gradient in the Eastern Atlantic Ocean based on COI 389 sequences. n, number of individuals of each species. St, number of stations where a species occurred. 390 GenBank, accession numbers of the COI sequences.

\begin{tabular}{|c|c|c|c|c|c|c|}
\hline ORDER & FAMILY & GENUS & SPECIES & $\mathbf{n}$ & St & GenBank \\
\hline \multirow{3}{*}{ Anguilliformes } & Congridae & Conger & Conger conger & 1 & 1 & KU902905 \\
\hline & \multirow{2}{*}{ Ophichthidae } & Dalophis & Dalophis imberbis & 1 & 1 & KU902930 \\
\hline & & Myrophis & Myrophis punctatus & 1 & 1 & KU902940 \\
\hline Argentiniformes & Microstomatidae & Batylagoides & Batylagoides argyrogaster & 2 & 1 & KU902900 \\
\hline \multirow{3}{*}{ Aulopiformes } & Evermannellidae & Evermanella & Evermanella balbo & 1 & 1 & KU902909 \\
\hline & Paralepididae & Macroparalepis & Macroparalepis affinis & 1 & 1 & KU902936 \\
\hline & Scopelarchidae & Benthabella infans & Benthabella infans & 1 & 1 & KU902901 \\
\hline Lophiiformes & Melanocetidae & Melanocetus & Melanocetus johnsonii & 1 & 1 & KU902937 \\
\hline \multirow{24}{*}{ Myctophiformes } & \multirow{24}{*}{ Myctophidae } & Benthosema & Benthosema suborbitale & 4 & 1 & KU902902 \\
\hline & & Bolinichthys & Bolinichthys indicus & 5 & 3 & KU902903 \\
\hline & & Ceratoscopelus & Ceratoscopelus maderensis & 1 & 1 & KU902904 \\
\hline & & \multirow{3}{*}{ Diaphus } & Diaphus brachycephalus & 1 & 1 & KU902931 \\
\hline & & & Diaphus holti & 1 & 1 & KU902907 \\
\hline & & & Diaphus rafinesquii & 8 & 2 & KU902908 \\
\hline & & Diogenichthys & Diogenichthys atlanticus & 3 & 2 & KU902932 \\
\hline & & \multirow{3}{*}{ Hygophum } & Hygophum hygomii & 22 & 3 & KU902912 \\
\hline & & & Hygophum macrochir & 24 & 5 & KU902913 \\
\hline & & & Hygophum taaningi & 1 & 1 & KU902914 \\
\hline & & Lampadena & Lampadena pontifex & 1 & 1 & KU902915 \\
\hline & & \multirow{3}{*}{ Lampanyctus } & Lampanyctus alatus & 1 & 1 & KU902934 \\
\hline & & & Lampanyctus nobilis & 1 & 1 & KU902916 \\
\hline & & & Lampanyctus pusillus & 3 & 2 & KU902917 \\
\hline & & Lepidophanes & Lepidophanes guentheri & 4 & 1 & KU902935 \\
\hline & & Lobianchia & Lobianchia dofleini & 1 & 1 & KU902918 \\
\hline & & \multirow{4}{*}{ Myctophum } & Myctophum affine & 1 & 1 & KU902920 \\
\hline & & & Myctophum asperum & 1 & 1 & KU902921 \\
\hline & & & Myctophum obtusirostre & 1 & 1 & KU902938 \\
\hline & & & Myctophum selenops & 2 & 1 & KU902939 \\
\hline & & Notolychrus & Notolychrus valdiviae & 1 & 1 & KU902941 \\
\hline & & Notoscopelus & Notoscopelus resplendens & 5 & 2 & KU902922 \\
\hline & & Symbolophorus & Symbolophorus veranyi & 1 & 1 & KU902925 \\
\hline & & Taanngichthys & Taanngichthys minimus & 1 & 1 & KU902942 \\
\hline Pleuronectiformes & Pleuronectidae & Reinhardtius & Reinhardtius hippoglossoides & 2 & 2 & KU902924 \\
\hline Scombriformes & Gempylidae & Diplospinus & Diplospinus multistriatus & 2 & 1 & KU902933 \\
\hline Scorpaeniformes & Serranidae & Mycteroperca & Mycteroperca acutirostris & 1 & 1 & KU902919 \\
\hline Stomiatiformes & Gonostomatidae & Cyclothone & Cyclothone acclinidens & 1 & 1 & KU902928 \\
\hline
\end{tabular}




\begin{tabular}{|l|l|l|l|l|l|l|}
\hline \multirow{5}{*}{} & \multirow{3}{*}{} & Cyclothone braueri & 1 & 1 & KU902906 \\
\cline { 3 - 7 } & & \multirow{3}{*}{ Gonostoma } & Cyclothone livida & 1 & 1 & KU902929 \\
\cline { 3 - 7 } & & Gonostoma denudatum & 1 & 1 & KU902910 \\
\cline { 3 - 7 } & & Gonostoma elongatum & 2 & 1 & KU902911 \\
\cline { 3 - 7 } & Stomiidae & Astronethes & Astronethes richardsonii & 1 & 1 & KU902899 \\
\hline Stomiiformes & Phosichthyidae & Vinciguerria & Vinciguerria nimbaria & 2 & 2 & KU902926 \\
\hline \multirow{2}{*}{ Stromateiformes } & \multirow{2}{*}{ Nomeidae } & Cubiceps & Cubiceps baxteri & 1 & 1 & KU902927 \\
\cline { 3 - 7 } & & Psenes & Psenes arafurensis & 2 & 2 & KU902923 \\
\hline
\end{tabular}

393 
Diogenichthys atlanticus

Hygophum hygomii Lampanyctus alatus Lampanyctus pusillus

\begin{tabular}{|l|l|}
\hline $\begin{array}{l}\text { Diagnosis } \\
\text { time }\end{array}$ & $\begin{array}{l}\text { Depth } \\
\text { range }\end{array}$ \\
\hline
\end{tabular}

$0-1050$

\section{0-1485}

\section{0-1500}

$15 \min$

$15 \mathrm{~min}$

$10 \mathrm{~min}$

40-850

244-1948

Max
length

2.9

6.8
6.1

6.1
4.3

6.1
4.3

8.5

\section{Soft rays}

\begin{tabular}{|l|l|l|}
\hline Dorsal & Anal & Pectoral \\
\hline
\end{tabular}

\begin{tabular}{|l|l|l|}
\hline \multicolumn{2}{|l|}{ Gill rakers } & \multicolumn{2}{l}{} \\
\hline $\begin{array}{l}\text { Lower } \\
\text { limb }\end{array}$ & Upper limb & $\begin{array}{l}\text { Other diagnostic } \\
\text { traits }\end{array}$ \\
\hline
\end{tabular}

$\begin{array}{ccc}10-12 & 15-18 & 12-14 \\ 13-15 & 21-23 & 14-17 \\ 11-13 & 16-18 & 11-13 \\ 11-13 & 13-15 & 13-14 \\ 12-14 & 17-20 & 12-16\end{array}$

$\begin{array}{lll}10-13 & 2-2 & \\ 14-17 & 5-6 & \begin{array}{l}\text { Big eyes characteristic } \\ 8-10\end{array} \\ 8-10 & 3-4 & \\ 10-12 & 3-5 & \text { Anal organs }\end{array}$

397

Table 4: Total cost estimation for the identification of the 30 individuals of the five species considered ( $\mathrm{n}=$ number of individuals of each species) found in the sampling stations, based on the time required for the analysis (at left) and consumables/external sequencing (right). Spanish salaries for laboratory technicians were taken from the official Resolution 2000 BOE 49 of 26 of February of 2015.

\begin{tabular}{|c|c|c|c|c|c|c|c|}
\hline & \multirow[b]{2}{*}{$\mathrm{n}$} & \multicolumn{4}{|c|}{ Diagnosis time (min labour) } & \multicolumn{2}{|c|}{ Consumables \& external analysis } \\
\hline & & Visual & \multicolumn{3}{|c|}{ DNA barcoding } & Visual & DNA barcoding \\
\hline & & & Tissue sampling & $\begin{array}{c}\text { DNA } \\
\text { extraction }\end{array}$ & PCR preparation & & \\
\hline Diogenichthys atlanticus & 3 & $15 \min \times 3=45$ & $2 \min x 3=6 \min$ & & & Fixative & Extraction kit \\
\hline Hygophum hygomii & 22 & $10 \min x 22=220$ & $2 \min \times 22=44 \min$ & & & & PCR products \\
\hline Lampanyctus alatus & 1 & $15 \min x 1=15$ & $2 \min x 1=2 \min$ & $15 \mathrm{~min}$ & $30 \mathrm{~min}$ & & Sequencing \& BLAST \\
\hline Lampanyctus pusillus & 3 & $15 \min \times 3=45$ & $2 \min \times 3=6 \min$ & & & & \\
\hline Myctophum asperum & 1 & $10 \min x 1=10$ & $2 \min x 1=2 \min$ & & & & \\
\hline Total time & & $335 \mathrm{~min}$ & & $5 \mathrm{~min}$ & & & \\
\hline Estimated cost & & $60.5 €$ & & $18.97 €$ & & $1 € \times 30=30 €$ & $5 € \times 30=150 €$ \\
\hline
\end{tabular}


404 Figure 1. Map showing the sampling stations along the Polarstern travel.

405

406

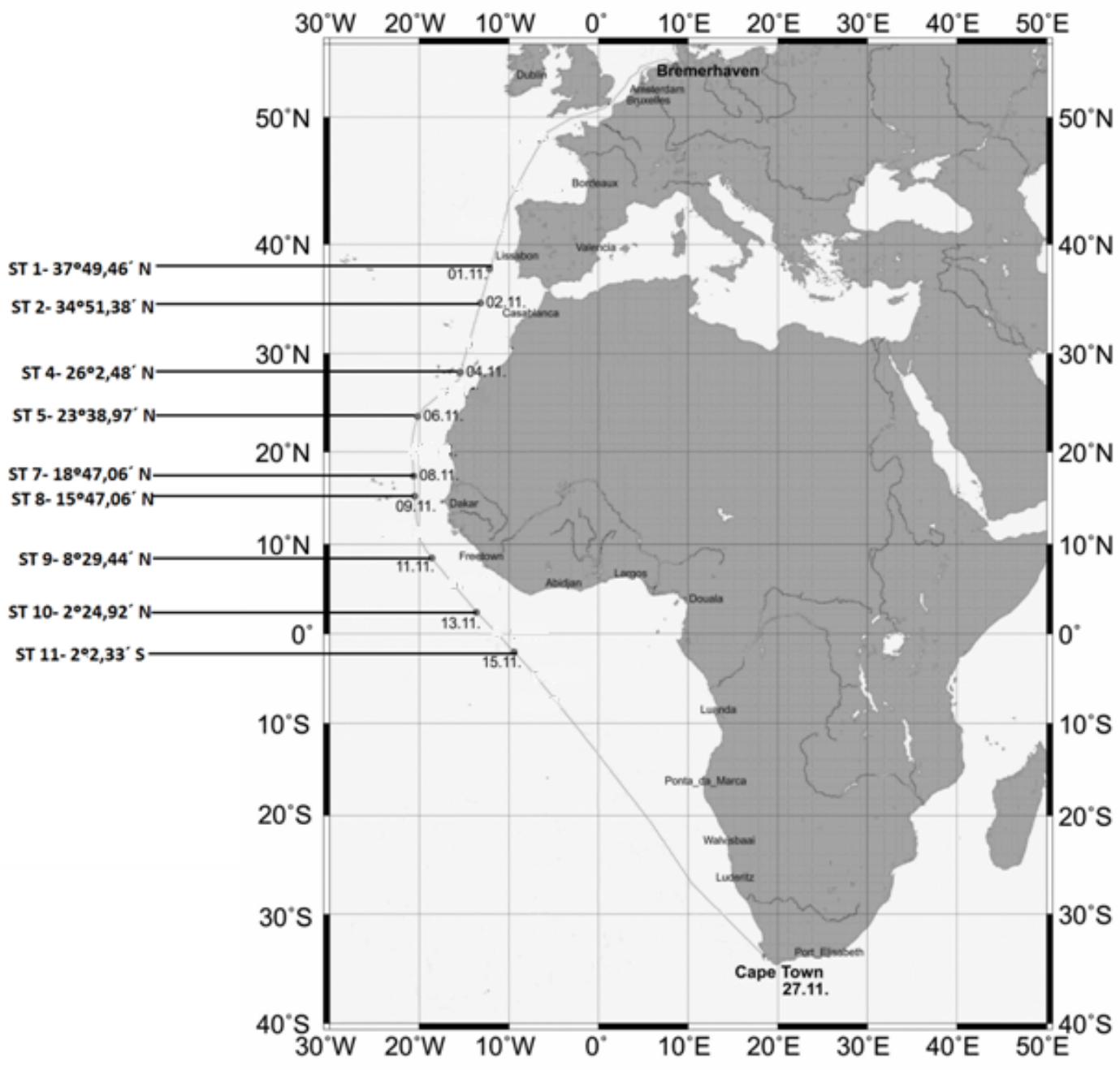

407 
408 Figure 2. Neighbour-Joining tree constructed based on COI gene haplotypes decribed in Table 2.

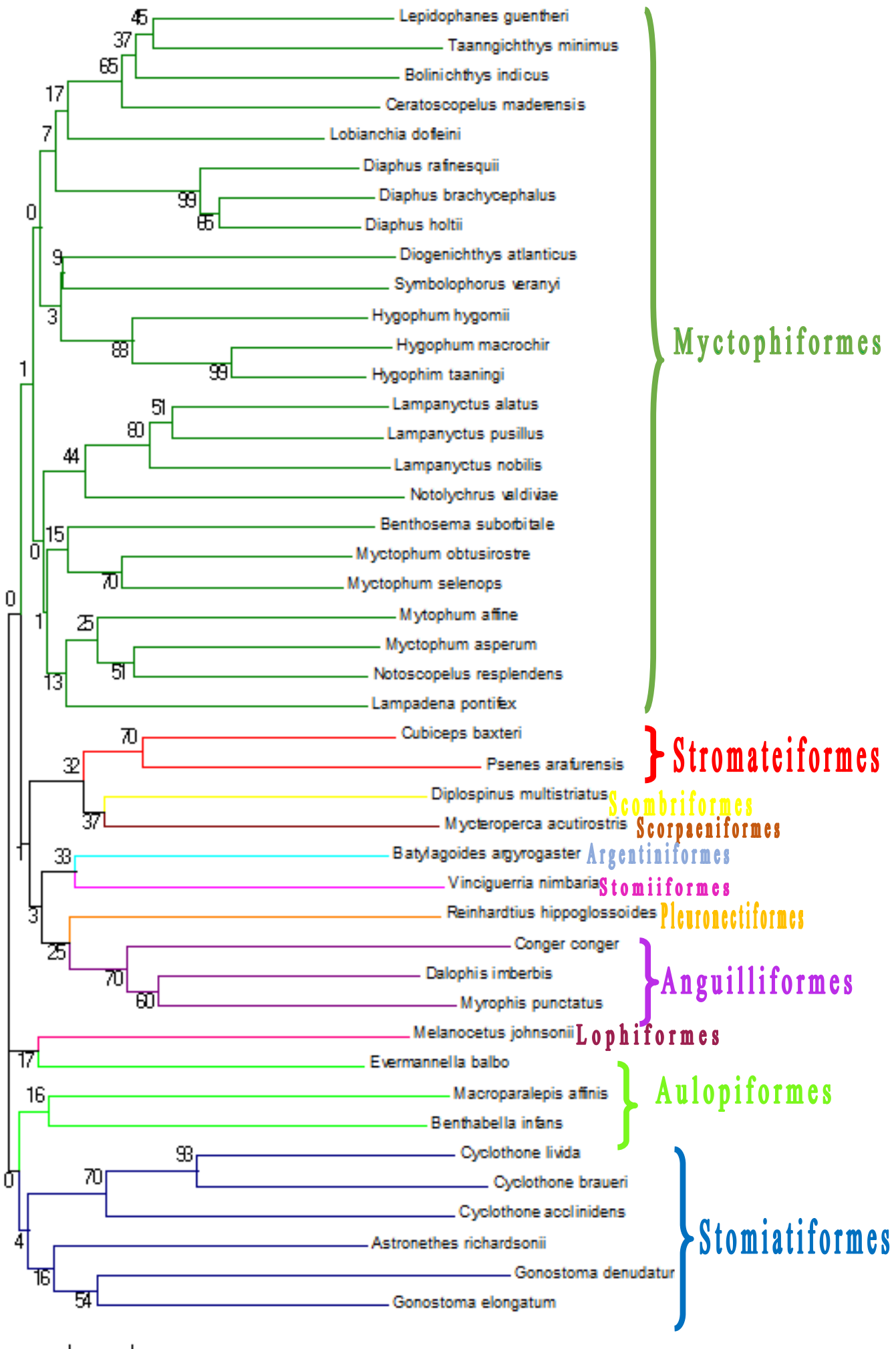

एवस 
412 Figure 3. Level of taxonomic resolution of the planktonic fish analyzed obtained from COI gene 413 sequences and nBLAST methodology, for each order. In parenthesis is the sample size.

414

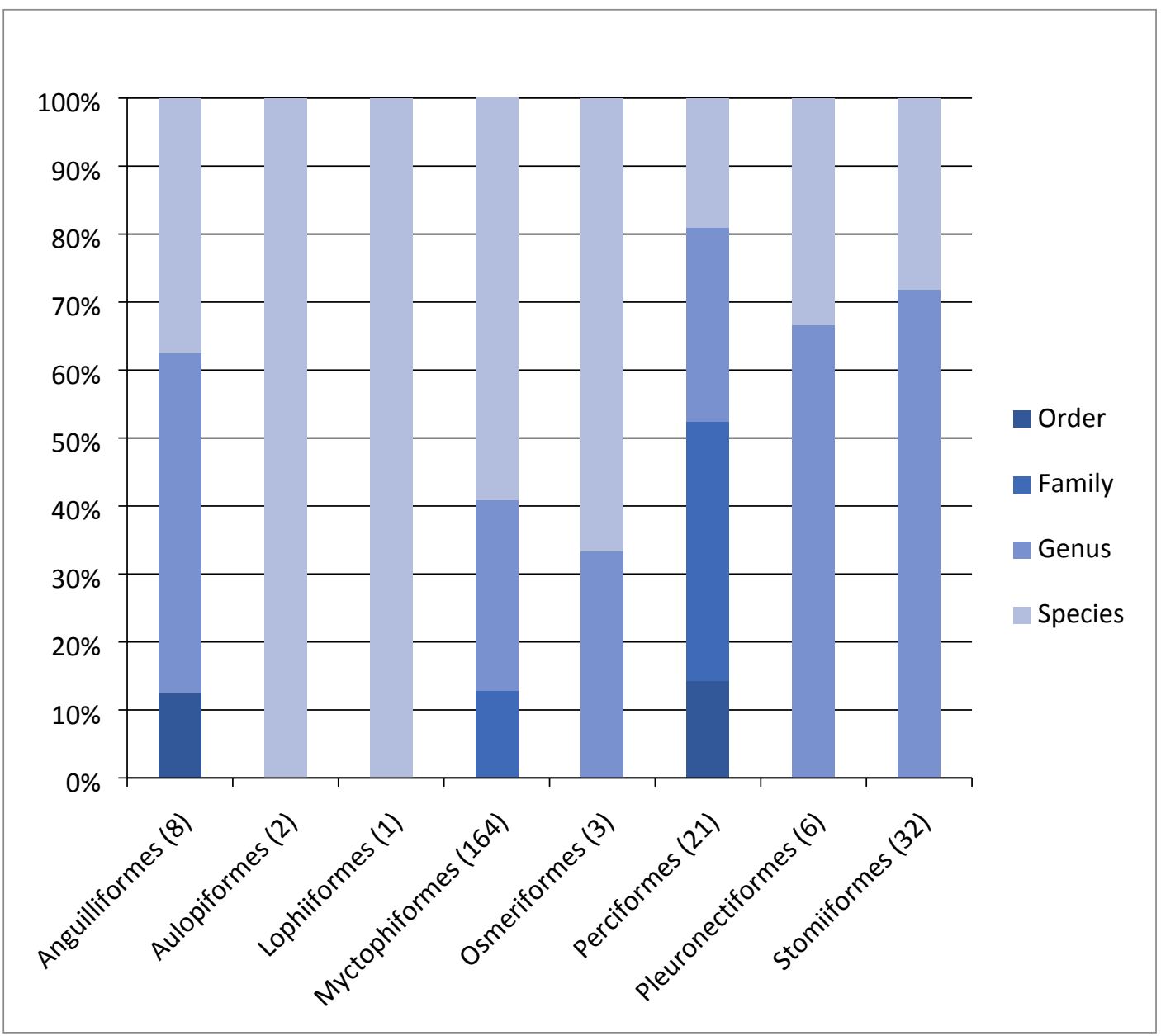

415

416

417 
418 Figure 4. Taxonomic resolution of the individuals sampled from each station (St), obtained from DNA 419 barcoding. Sample size in parenthesis.

420

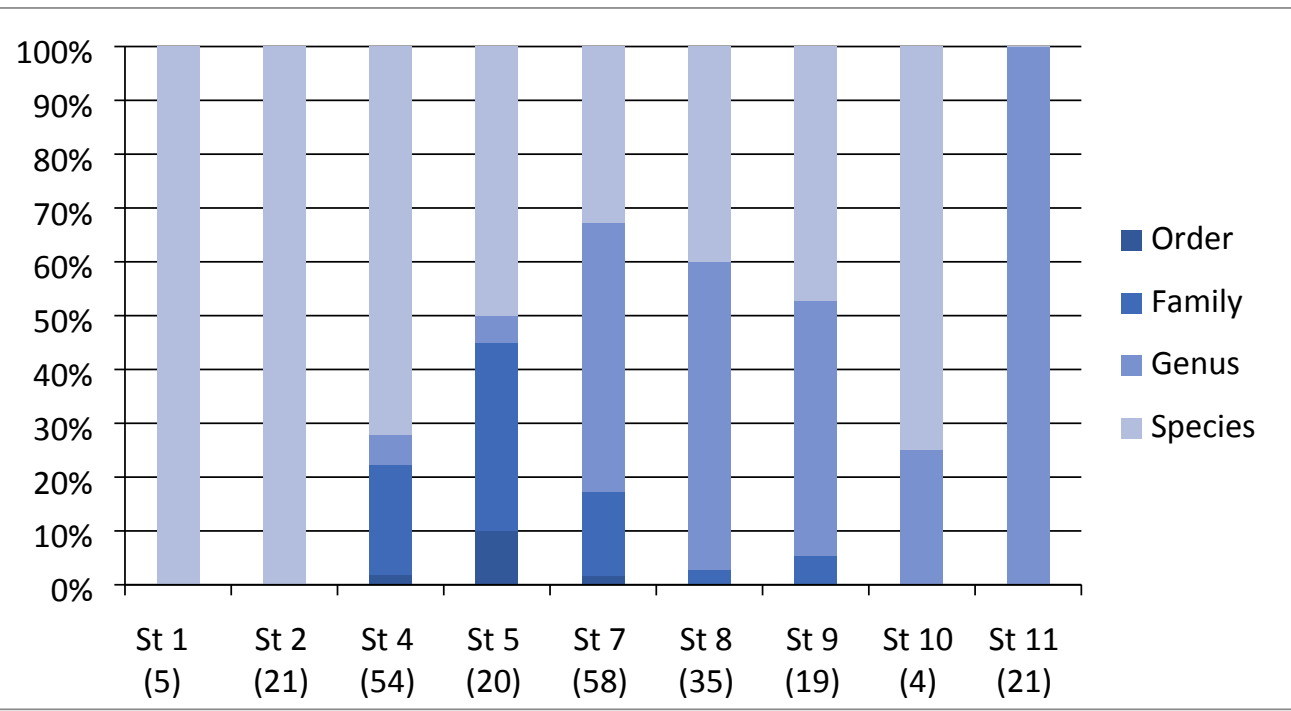

